Information Management and Business Review

Vol. 5, No. 10, pp. 477-481, Oct 2013 (ISSN 2220-3796)

\title{
Bernanke's Test: Ben Bernanke, Alan Greenspan, and the Drama of the Central Banker
}

\section{Book Review}

\author{
Author: Johan Van Overtveldt \\ Reviewed by: Shiva Kumar Srinivasan \\ Behavioral Sciences, IIPM Chennai, India \\ sksrinivasan2008@hotmail.com
}

\section{Introduction}

When and how did central banking become 'dramatic' in character? That is the question that Johnan Van Overtveldt sets out to answer in this splendid introduction to the drama of being a central banker. All drama, as literary critics will vouch for, is based on the notion of a conflict that is real, imaginary or symbolic; a conflict is a clash of values between the main protagonists who are caught up in a piece of action. The main protagonists here however are not just central bankers, but include a number of financial institutions that collapsed in 2008 and had to be bailed out by the US Federal Reserve. So, contrary to what the title implies, the main symbolic conflict that is depicted in this book is not between Greenspan and Bernanke as such; this is a theme that was broached just a year before the publication of this book (by Harris, 2008). The conflict is more in the nature of what kind of policy intervention central banks should make when the financial system is enmeshed in a crisis. The monetary conflict, if any, relates to the 'scale-and-scope' of monetary policy interventions and on whether or not such interventions should precede or follow the emergence of a financial crisis. The term that Federal Reserve economists use for this clash of values pertains to whether they should 'lean against the wind'. This basically means that they are not certain about whether it is a part of their responsibility to spot and deflate asset bubbles before they burst since they are not sure whether these are real or imaginary phenomena given that the valuation of assets is problematic during a bubble. Another interesting image of this policy uncertainty is again whether they should 'take away the punch bowl after the party gets going' without coming across as a bit of a spoil-sport.

So whether economic trends that might precipitate a bubble are compared to a force of nature (wind in this instance) or the quantity of punch required to sustain a party, there is some uncertainty in terms of what in fact constitute the right monetary policy values. These monetary values pertain to macroeconomic assumptions about 'if-and-when' a policy intervention is required and what the extent of the Fed's intervention should be. The search for monetary policy 'rules' (such as the Taylor rules and variations thereof) as opposed to 'a discretionary regime' is based precisely on this uncertainty about values and whether monetary policy can be done on auto-pilot; and, if yes, whether it is desirable to do so. Would this not- as some Fed watchers are bound to wonder - amount to asking the FOMC to talk-its-way-out-of-a-job? There is also the question of precedents and tools in monetary policy. Would a rules-based approach (that reduces the dramatic element of monetary policy administration) be mechanically tied to monetary precedents? Would a rules-based approach work in a crisis? Or is it rather the case that a strict adherence to a rules-based approach will always be able to prevent the emergence of a financial crisis? Or should the Fed oscillate between a rules-based approach when the going is good and switch to discretion if it has to intervene urgently? There is also the question of whether or not the term 'rules' should be interpreted in a strong sense - i.e. a rule does not have to be an iron-clad rule; and discretion does not mean that 'anything goes' by way of policy. 


\section{The Taylor Rule}

A dramatic representation of this policy conflict might be to conduct a thought experiment with John Taylor as Chairman of the Fed. Would it be politically or even technically possible for John Taylor to follow the Taylor rule without exception if he were chairman? If yes, why? If not, why not? One form of dramatic representation then that will help us to envisage Fed policy is to do a 'scenario-analysis' with Taylor as Chairman. Another important point to remember is that Taylor will be able to follow the Taylor rule only if his predecessor(s) at the Fed had also followed the Taylor rule. If that were not the case, Taylor would have to push a 'discretionary' approach in the short term before it becomes technically possible for the Fed to stick to the Taylor rule; this is implied in Taylor's argument though he may not say so directly (Taylor, 2006; Taylor, 2007). It is also important to remember that Taylor is not the only economist who is in favor of a rules-based approach to monetary policy. How would the Fed - should it decide to fly auto-pilot - approach a plethora of rules that monetary theorists are obsessed with (Taylor, 2007)? What about instances when the Fed has to go beyond the conventional approaches and try unconventional approaches to monetary policy when the federal funds rate is already zero bound? Would a rules-based approach to monetary policy have anything much to say in such a scenario? Introducing scenario-based analyses (as the Fed does every now and then in its press conferences) across a range of interest rates is not only an important way of thinking about policy options in the context of doing monetary policy, but is also an important cognitive tool for the Fed to communicate effectively what it is doing. These then are some of the important questions that readers may want to thinkthrough as a result of reading the history of monetary policy that Overtveldt prefaces to his engagement with the recent, and not-so recent, policy articulations of the Fed since it was founded by the Federal Reserve Act of 1913.

\section{The Question of Knowledge}

There are two parts to this book. The first describes the Greenspan era; the second, the Bernanke era. Both these parts have a similar structure: the main problem here is the question of knowledge. What kind of knowledge is required to be a central banker? The answer to this may seem to be obvious: knowledge of central banking. But what is really at stake is not knowledge in the sense of having read and written about central banking, but knowledge of how central banks must design their interventions when they have to go beyond their traditional responsibility of setting the federal funds rate (which is the rate at which banks lend to each other). The fact that the federal funds rate is the main tool that central banks have at their disposal does not make for much drama. What is it then that justifies the invocation of the dramatic? The answer to this question is that the federal funds rate is enough to direct the economy when it is business as usual, but takes on a dramatic cast when interest rates hit the zero bound, which can be defined as the Newtonian edge of macroeconomic assumptions (Capra, 1983). What happens at this point though is that the Federal Reserve doesn't have a lever that it can push decisively if the economy does not revive when interest rates hit zero. At this point, even the most confident, instrumental, and pragmatic of central bankers will turn philosophers. They will begin to wonder about the relationship between 'cause' and 'effect' given their preoccupation with the velocity of the circulation of money. Central bankers also know that monetary policy is only half the story and requires a healthy measure of co-ordination with fiscal policy. The implicit question for them is whether macroeconomics is really a science (Prescott, 2006). Any lack of coordination between the monetary and fiscal authorities will exacerbate a financial crisis and slow down the pace of recovery; that is why the good teamwork between Ben Bernanke at the US Fed, Hank Paulson at the US Treasury, Christopher Cox at the SEC, and Sheila Bair at the FDIC garnered a lot of attention (Bartiromo \& Whitney, 2010; Grunwald, 2009/2010; Paulson, 2010). Not many either anticipated or even expected the teamwork amongst these regulators to be much of a success making it easier for them to exceed expectations. 


\section{The Dual Mandate}

The dramatic elements that Overtveldt calls attention to then can be understood as the following: the approach to the zero bound in the federal funds rate, the presence or absence of co-ordination between monetary policy and fiscal policy, and the continuity or lack of continuity between the policy initiatives of the Federal Open Market Committee (FOMC) in the present and in the past. These three features are what constitute the dramatic cast of monetary policy and not - as some people fancifully believe - personality clashes as such between Greenspan and Bernanke. If anything, for all their similarities and differences, Fed chairmen and the past and present members of the FOMC are extremely careful to preserve the semblance of continuity in monetary policy. Dissenting opinions are few and far between and are more likely to occur between the Fed and the regional Reserve Bank presidents depending on the cast of 'hawks' (who favor high interest rates) and 'doves' (who favor lower interest rates) rather than in the Federal Reserve in Washington DC per se. The dramatic character of central banking then has to be understood mainly as a problem of policy conflicts engendered in the process of figuring out what exactly the quanta of intervention should be in monetary policy, and what policy options remain after the federal funds rate hits the zero bound. The dramatic elements of the conflict can also be understood in terms of the Congressional insistence on the 'dual mandate'; which requires the Federal Reserve to pursue both 'price stability' and 'maximum employment' as its policy goals. It is worth asking what the trade-offs are in pursuing both these objectives when it is business-as-usual and in times of crisis (Goodfriend, 2007).

\section{Inflation Targeting}

This however is not the case in many parts of the world where central bankers follow an approach that is described as 'inflation targeting' - a topic incidentally that Bernanke and a number of central bankers were preoccupied with for years (Bernanke, 2004). The main difference then between European and American approaches to monetary policy is this: the Europeans are mainly preoccupied with inflation targeting and leave fiscal policy to worry about the employment numbers; the American approach to monetary policy is however 'mixed': it incorporates elements like maximizing employment that should belong strictly speaking to fiscal policy. The main difference between the Greenspan and Bernanke approaches is that Bernanke is more preoccupied with making a success of the 'dual mandate'. In fact, a lot of Fed watchers were not even aware that the Fed had a dual mandate or that it took this mandate seriously until Bernanke made it an important part of both his communication policy and monetary policy by raising this matter repeatedly in press conferences and FOMC meetings. Not many expected an inflation target to take the dual mandate seriously though Bernanke has proved his critics wrong on this matter. The Paul Volcker regime at the Fed of the 1970s is an early prototype of 'inflation-targeting'. This was much before that term gained currency in European approaches to monetary theory and monetary policy under the aegis of the European Central Bank, or even earlier, under the authority of the Deutsche Bundes bank in the era of the Great Moderation (Issing, 2005). While it is important to compare the Greenspan and Bernanke eras, it is equally important to take a 'comparative approach' to central banking to understand the constraints on the Federal Reserve. This, needless to say, is the method that Bernanke himself pushes in his studies of the Great Depression to identify the 'causative' factors in economic history in the United States as opposed to Europe. The whole question of the 'money-gold ratio' in the monetary base, and the time-and-effort required to pull the economy out of the 'economic contraction', for instance, will not make much sense as a causative factor without the invocation of comparative economic data (Bernanke, 2000). The comparative method is also at stake, for instance, in the 'rules versus discretion' debate. What is at stake in this debate is asking whether giving 'political independence' to a central bank is a superior option in terms of monetary policy outcomes as opposed to 'a monetary rule based performance'. It is more likely that we will be able to answer this question and its 
implications, for instance for the Taylor rule, if we work, as economists are increasingly doing, with comparative data (Alesina and Summers, 1993).

\section{Conclusion}

Making sense of these questions then requires that we return to the question of education. How should central bankers be educated (Lowenstein, 2008)? What are the criteria that we must identify to determine the success of central bankers when they are appointed to high office (Bernanke, 2005)? The significance of these questions relates to the fact that Greenspan had a non-academic background while Bernanke is the quintessence of the academic economist. There is also some speculation on whether he considers himself a macroeconomist or an economic historian though in his own estimation he is the former rather than the latter (Abel, Bernanke, and Croushore, 2013). The main source of dramatic excitement in these speculations is the 'happy-coincidence' between Bernanke's educational background and the fact that he had to save the economy from what might have been another Great Depression which he was determined to avoid by doing whatever it takes (Wessel, 2009). Since the odds of any academic economist being appointed Chairman of the Federal Reserve are not very high, how are we to make sense of this happy coincidence? It appears in retrospect that Bernanke was preparing precisely for this moment: chance indeed favors the prepared mind! It is this spirit in Bernanke's approach (that should not be misconstrued as just another version of 'the Greenspan put' given the negative connotations of the 'moral-hazard' problem) that Overtveldt leaves the reader with when he concludes the book with an anecdote that describes Bernanke apologizing to Milton Friedman and Anna Schwartz. The occasion for this apology was the ninetieth birthday of Milton Friedman. Bernanke pointed out that Friedman and Schwartz were right in blaming the Fed for contracting the money supply at the wrong time: 'Regarding the Great Depression: You're right. We're very sorry. But thanks to you, we won't do it again' (p. 246). What Overtveldt succeeds in doing admirably then is in explaining to both academic and lay readers alike how Ben Bernanke went about doing so, and how the range of monetary precedents, and monetary policy tools that he and the FOMC innovated in this instance (Musacchio and Roscini, 2009) will force us to re-think the traditional ambit of both monetary theory and monetary policy.

\section{References}

Abel, A. B., Bernanke, B. S., and Croushore, D. (2013). Macroeconomics, 7th Edition (New York: Pearson/Prentice Hall).

Alesina, A. and Summers, L. H. (1993). 'Central Bank Independence and Macroeconomic Performance: Some Comparative Evidence', Journal of Money, Credit and Banking, 25(2), 151-162.

Bartiromo, M. and Whitney, C. (2010). The Weekend That Changed Wall Street: An Eye Witness Account (New York: Penguin/Portfolio Books).

Bernanke, B. S. (2000). 'The Macroeconomics of the Great Depression: A Comparative Approach', Essays on the Great Depression (Princeton and Oxford: Princeton University Press), 5-37.

Bernanke, B. S. (2004). 'Inflation Targeting', Federal Reserve Bank of St. Louis Review, Jul/Aug 2004, 165-183.

Bernanke, B. S. (2005). 'The Transition from Academic to Policymaker', Remarks by Governor Ben S. Bernanke at the Annual Meeting of the American Economic Association, Philadelphia, Pennsylvania, January 7, 2005.

Capra, F. (1983). 'The Impasse of Economics', The Turning Point: Science, Society, and the Rising Culture (New York: Bantam Books), 188-233.

Goodfriend, M. (2007). 'How the World Achieved Consensus on Monetary Policy', NBER Working Papers Series, Working Paper 13580, National Bureau of Economic Research, Cambridge, at: http://www/nber.org/papers/w13580.

Grunwald, M. (2009/2010). 'Ben Bernanke: The 2009 TIME Person of the Year', TIME, 174(25/26), 20-33. 
Harris, E. S. (2008). Ben Bernanke's Fed: The Federal Reserve After Greenspan (Boston: Harvard Business Press).

Issing, O. (2005). 'Communication, Transparency, Accountability: Monetary Policy in the Twenty-First Century', Federal Reserve Bank of St. Louis Review, March/April. Part 1, 65-83.

Lowenstein, R. (2008).'The Education of Ben Bernanke', The New York Times, January 20, 2008, available at: http://www.nytimes.com/2008/01/20/magazine/20Ben-Bernanke-t.html?

Musacchio, A. and Roscini, D. (2009). 'Necessity and Innovation: Monetary Policy Innovation and the Subprime Crisis', Harvard Business School, Case Number N9-709-041.

Paulson, H. (2010). On the Brink: Inside the Race to Stop the Collapse of the Global Financial System (London and New York: Headline Business Plus).

Prescott, E. C. (2006). 'Nobel Lecture: The Transformation of Macroeconomic Policy and Research', The Journal of Political Economy, 114(2), 203- 235.

Taylor, John B. (2006). 'Interview with John Taylor', Federal Reserve Bank of Minneapolis, June 2006, at: http://www.minneapolisfed.org/pubs/region/06-6/taylor.cfm.

Taylor, J. B. (2007). 'Housing and Monetary Policy', NBER Working Papers Series, Working Paper 13682, National Bureau of Economic Research, Cambridge, at: http://www.nber.org/papers/w13682.

Taylor, J. B. (2007). 'The Explanatory Power of Monetary Rules', NBER Working Papers Series, Working Paper 13685, National Bureau of Economic Research, Cambridge, at: http://www.nber.org/papers/w13685.

Wessel, D. (2009). In Fed We Trust: Ben Bernanke's War on the Great Panic (New York: Three Rivers Press), passim. 